DOI: $10.11649 / \mathrm{abs} .2014 .011$

\title{
Robert Zawisza
}

Instytut Slawistyki PAN

Warszawa

zawisza@pro.onet.pl

\section{Biografia nieobecna. Wokół życia i twórczości Ireneusza Plater-Zyberka}

„Głową, sercem i nogami! Od czasu, jak literatura świata istnieje, jest to pierwsza powieść napisana nogami..." - w ten sposób wydawca reklamował debiut książkowy Ireneusza Plater-Zyberka (Plater Zyberk, 1931, ss. 116-117). Pisarz, reżyser, producent filmowy, bawidamek i trochę włóczęga. Taki obraz wyłania się z kart jego autobiograficznej opowieści Życie bez rąk, opublikowanej własnym nakładem w 1931 r. Niezwykłość postaci Plater-Zyberka ${ }^{1}$ bierze się z faktu, że pomimo ułomności - urodził się bez rąk - osiągnął $\mathrm{w}$ dwudziestoleciu międzywojennym wymierny sukces. Los ludzi niepełnosprawnych w XIX w. i także po zakończeniu I wojny światowej, która przyniosła kalectwo tysiącom z nich, był tragiczny. Nasz bohater miał szczęście, że pochodził z zamożnej i wpływowej rodziny (Rubene, 2008, ss. 82-91; Malahovskis, 2012, ss. 563-567; Zawisza, 2013, ss. 141-142), co ułatwiło mu życiowy start i bez wątpienia pomogło w karierze. Dziś jest postacią zapomnianą, okazjonalnie wspomina się jego filmy fabularne, głównie „Martwy węzeł” (1927), i cenny film dokumentalny

${ }^{1}$ W źródłach pojawiają się różne formy zapisów nazwiska: Plater, Plater Zyberk lub Plater-Zyberk. Według tradycji rodzinnej pierwszy człon nazwiska pozostaje nieodmienny i zamiast zgodnej z normą języka polskiego odmiany w dopełniaczu liczby pojedynczej Platerów-Zyberków przyjmuje formę Plater-Zyberków (Konarski, 1967, ss. 15-17; „Rozmowa z Ireneuszem Plater Zyberkiem”, 1930, s. 10). 
„Salve Regina” (1935). Dwie powieści i wspomnienia pozostają nieznane, w każdym razie nie funkcjonują w obiegu literackim.

\section{Zapomniana postać}

Niniejszy artykuł jest rozszerzoną i poprawioną wersją artykułu zamieszczonego pod tym samym tytułem w tomie Biografia $w$ literaturze i sztuce (Zawisza, 2014, ss. 193-206). Pierwszą próbą opracowania faktów z życia i twórczości Ireneusza Plater-Zyberka był artykuł mojego autorstwa opublikowany w 2013 r. nakładem Uniwersytetu w Dyneburgu, w którym omówiłem stan badań i podałem szereg nieznanych dotąd ustaleń biograficznych (Zawisza, 2013). Tu chciałbym zwrócić szczególną uwagę na zjawisko autokreacji, na sposób w jaki autor przedstawia swoją osobę i tworzy własny wizerunek. Mamy bowiem do czynienia $\mathrm{z}$ interesującą próbą ukazania drogi do samodzielności życiowej i pokonywania przeciwności losu, który stał się udziałem osoby niepełnosprawnej. Ireneusz Plater-Zyberk świadomie przyznaje, że swój sukces zawdzięcza nie tyle własnym zdolnościom i uporowi, ile staraniom rodziny, zwłaszcza matki, zamożności i znakomitej genealogii.

Materiał źródłowy do poznania jego życia i twórczości jest skromny: wspomniana autobiografia, wywiady i recenzje z okresu międzywojennego, kilka rękopiśmiennych wzmianek i anonimowa nota biograficzna, prawdopodobnie część większego opracowania dziejów rodu, udostępniona mi przez Marka Plater-Zyberka („Ireneusz Plater”, ok. 1960, ss. 1-2). Bardzo ciepło zapisała się postać Ireneusza w pamięci żyjących członków rodziny. Mimo braku rąk odznaczał się dużą siłą i sprawnością, był pełen witalności i niezwykłych pomysłów, jednocześnie lekkomyślny i skłonny do nieroztropnego wydawania pieniędzy. Jego fascynującą postać przypomniała ostatnio Róża Thun - po matce wywodząca się z Plater-Zyberków - w swojej autobiograficznej opowieści (Thun, 2014, s. 29).

Poza odnotowaniem filmów zrealizowanych przez Ireneusza Platera w katalogach i leksykonach filmowych w ciągu ostatniego półwiecza pojawiło się zaledwie kilka cząstkowych opracowań odnoszących się wyłącznie do jego aktywności filmowej. Adam Wyżyński i Grażyna Kuźnik w popularnej publikacji zajęli się filmem dokumentalnym „Salve Regina” o sanktuarium w Piekarach na Górnym Śląsku (Wyżyński, 2007, s. 478; Kuźnik, 2012). Irena Nowak-Zaorska w opublikowanej rozprawie doktorskiej poświęciła nieco uwagi działalności Ireneusza Plater-Zyberka na rzecz zmian w prawodawstwie dotyczącym filmu dokumentalnego. Przypomniała, że w latach 1933-1939 był on wiceprezesem Związku Producentów Filmów Krótkometrażowych. Omówiła przy tym najlepszy, jak można sądzić, jego film „Zew trombity” (1934) o folklorze górali huculskich w Karpatach Wschodnich (Nowak-Zaorska, 1969, ss. 144-148, 152 i in.). Plater-Zyberk wraz z innymi producentami i reżyserami zaczęli kręcić w latach 30. 
ubiegłego wieku filmy średniometrażowe, liczące niekiedy ponad godzinę emisji. Film dokumentalny przestał być tylko kronikarską rejestracją jakiegoś zdarzenia, lecz stawał się opowiedzianą wielowątkową historią, reportażem.

W artykule przedstawię wybrane aspekty życia i twórczości Ireneusza Plater-Zyberka, które nasz bohater obrazowo ukazał na kartach Życia bez rąk. Dzieciństwo i młodość spędzone na Łotwie w rodzinnym majątku Wabol w dawnym powiecie dyneburskim odegrały szczególną rolę w jego życiu, umożliwiły mu późniejszą aktywność zawodową i towarzyską. Dydaktyczna i motywacyjna rola jego książki opiera się na przesłaniu autora, na wyraźnej sugestii, że człowiek ułomny ${ }^{2}$, jak nazywa niepełnosprawnych, może stać się kimś wartościowym. Jest w stanie pozostawić po sobie trwały i ważny ślad. Życie bez rąk odwołuje się do doświadczeń dzieciństwa i młodości, i w tym zakresie stanowi wartościowe, aczkolwiek subiektywne źródło biograficzne. Jego działalność literacką i filmową musimy układać na nowo z niewielkich śladów i wzmianek, które pozostały w prasie codziennej i fachowej. Bez odnalezienia dokumentów i przekazów o charakterze osobistym obraz pozostanie niepełny.

\section{Dzieciństwo i młodość}

Ireneusz Plater-Zyberk urodził się w 1896 r. w Wabolu (łot. Vabole) na Łotwie. Nie można jednak wykluczyć, że przyszedł na świat w roku następnym ${ }^{3}$. Ojciec, Teofil Stanisław (1862-1917), był ziemianinem z gałęzi inflanckiej rodu Platerów (Konarski, 1967, s. 92). Matka Jadwiga pochodziła z Chrapowickich, średniozamożnej rodziny ziemiańskiej z terenów dzisiejszej Białorusi, była osobą pobożną, pozostawiła po sobie sentymentalne, dydaktyczne powieści Stokrotka, Niezapominajka i Elżunia, wszystkie napisane u schyłku życia i wydane w dwudziestoleciu międzywojennym (Konarski, 1967, s. 92). Autor zwraca uwagę, że matka $\mathrm{z}$ własnej inicjatywy zorganizowała ochronkę dla „upadłych” dziewcząt, dla matek z bękartami. Nie pochwalała ich zachowania, ale z drugiej strony nie mogła pozostawić nieszczęsnych kobiet bez żadnej pomocy (Plater Zyberk, 1931, ss. 54-55). Postawa matki - czytamy na kartach Życia bez rąk- miała największy wpływ na ukształtowanie się postawy późniejszego twórcy. Ojciec pojawia się we wspomnieniach jako dobry gospodarz, troszczący się o bezpieczeństwo i materialny byt rodziny, człowiek wyrozumiały dla innych.

${ }^{2}$ Świadomie używam pojęcia „ułomny” zamiast „niepełnosprawny”, gdyż tak nazywał siebie we wspomnieniach sam autor. W autobiografii i w przekazach prasowych często pojawia się neutralne, pozbawione wartościowania określenie „bezręki”, zob. „Rozmowa z Ireneuszem Plater Zyberkiem”, 1930, s. 10.

${ }^{3}$ W kwestionariuszu spisu powszechnego ludności Cesarstwa Rosyjskiego na dzień 28 stycznia 1897 r. Ireneusz Plater-Zyberk nie został wymieniony. Należy zaznaczyć, że dokument zawiera szereg rozbieżności z zachowanymi metrykami urodzenia innych członków rodziny („Latvijas Valsts vēstures arhīvs", ok. 1897, f. 2706, apr. 1, lieta 117, p. 179-180). 
Swoje wspomnienia Plater-Zyberk zaczął mitologicznie, tak jak nakazywał kanon pisania dziejów znamienitych rodów. Matka, będąc we Włoszech, zobaczyła kalekiego człowieka bez rąk, który przychodzi na grób kogoś bliskiego o imieniu „IRENEUS”. Kim był, dlaczego odwiedzał grób - nie wiadomo. Złożyła obietnicę, że jeśli urodzi się syn nazwie go właśnie Ireneusz (Plater Zyberk, 1931, ss. 29-32). Urodziło się dziecko bez rąk - wielka konsternacja dla rodziny. Co robić? Jest to zapewne licentia poetica autora, ale należy do szablonu, wzoru, jak pisać dzieła genealogiczne. Początki rodu powinny być niezwykłe - okupione bohaterskim, często nadludzkim czynem, lub mityczne, na wpół boskie. Osoby postronne mogły tłumaczyć narodziny dziecka bez rąk jako karę Boską za domniemane grzechy rodziców, tym bardziej że pierwsze z dzieci zmarło krótko po narodzinach (Sardyko, 1997, s. 111; Konarski, 1967, s. 92).

Ireneusz Plater-Zyberk opuścił Łotwę na przełomie 1918 i 1919 r. Niewiele brakowało, a skończyłby jak setki ziemian i ludzi zamożnych, powieszony albo rozstrzelany (Sawicz, 2006, ss. 180-181). Prawdopodobnie jesienią 1917 r., krótko przed wybuchem rewolucji październikowej, został wiceprzewodniczącym komitetu rewolucyjnego bolszewików w Wabolu, co po dwóch miesiącach skończyło się ucieczką z majątku. Delegaci z Petersburga przekonali włościan, że nie tylko dla ziemian, ale również dla niepełnosprawnych nie ma miejsca w rzeczywistości sowieckiej:

Rozumiem dobrze całe przywiązanie i zaufanie, jakiem obdarzacie waszego towarzysza-hrabiego - parafrazuje autor przemówienie jednego z delegatów - Zrozumcie jednak, że dziś, gdyśmy po tysiącach lat krwawym znojem zdobyli naszą wolność, dziś, powtarzam, nie mamy czasu ani prawa unosić się sentymentem, choćby najszlachetniejszym. Świat, który w wielkim chrzcie rewolucji urodził się na nowo, wymaga jednostek silnych, zdolnych do pracy i to do niebylejakiej pracy! A oto tu przede mną siedzi człowiek ułomny, obu rąk pozbawiony, człowiek który nie będzie w stanie nawet zaorać kawałka ziemi, co mu komitet przydzieli. Może mi ktoś powie, że nie mając rąk, może on pracować głową? Owszem. A jednak w życiu codziennem, w czynnościach fizycznych, będzie on musiał szukać zastępstwa rąk osób trzecich. I w swoim choćby małym zakresie wprowadzi znowu w życie pierwiastek zapłaty za najemne ręce i ucieleśni, nawet mimowolnie może, teorję wyzysku pracy przez pieniądz [...].

I wówczas stało się coś dziwnego. Gdy przebrzmiały ostatnie słowa mówiącego, nieprzeniknione milczenie trzymało przez chwilę jeszcze w swych kleszczach gromadę. Aż nagle, kto żyw, wrzasnął:

- Dobrze mówi! Prawidłowo mówi! Na szubienicę z krwiochłeptaczem! Pod ścianę go! (Plater Zyberk, 1931, ss. 184-185).

Życie uratował mu ktoś ze służby, wyprowadzając w zamieszaniu autora wspomnień na tyły oficyny i umożliwiając ucieczkę konno. Nie udało się znaleźć innego, poza relacją w autobiografii, potwierdzenia rewolucyjnej działalności Plater-Zyberka. Za wiarygodnością opisu przemawia fakt, że w Polsce po 1926 r. organy państwa 
zwalczały działalność komunistyczną i niewiele osób publicznie przyznawało się do związków z bolszewizmem, nawet jeśli miałby to być krótkotrwały epizod.

W sylwestrowy wieczór $1918 \mathrm{r}$. Ireneusz Plater-Zyberk opuszcza Łotwę i udaje się na dwuletnią emigrację do Danii. Wrócił na Łotwę ponownie w 1920 r. w związku z nacjonalizacją majątku Wabol:

Lecz oto pociąg pędził już ku granicy łotewskiej. Aż wreszcie ujrzałem zgliszcza ojcowizny. Pełen energii roiłem plany odbudowy po to tylko, by stanąć niebawem wobec faktu dokonanego, który przechrzczono z przestarzałego miana „konfiskata” na współczesne określenie „reforma agrarna”.

Zastosowano ją w najostrzejszej formie przeciw mniejszościom narodowym, recte przeciw Polakom, co mogli wpływem kulturalnym stać na przeszkodzie złotewszczeniu prastarej prowincji polskiej - Inflant, co przynależność swą do Polski Zygmuntowi Augustowi dobrowolnie zdeklarowały, a splendor swój Batoremu zawdzięczyły (Plater Zyberk, 1931, ss. 207-208; Łossowski, 1990, ss. 20-21).

Niestety, cofnięcie decyzji władz o upaństwowieniu dóbr ziemskich okazało się niemożliwe ${ }^{4}$. Ireneusz reprezentował na miejscu swoich braci, którzy w tym czasie walczyli na froncie przeciwko armii bolszewickiej. Zresztą starszy brat, Henryk zginął jako oficer kawalerii w czasie walk pod Kijowem i pośmiertnie został odznaczony krzyżem srebrnym Virtuti Militari (Plater Zyberk, 1931, ss. 208-209; Konarski, 1967, ss. 92-93). W czasie ostatniego pobytu na Łotwie Plater-Zyberk odnowił znajomość z Janiną Kozieradzką i po wielu perypetiach w 1920 r. zawarł związek małżeński. Niestety, małżeństwo przetrwało zaledwie kilka lat, po czym już około 1928 r. nasz bohater związał się z Ireną (Irmą) Radko, młodszą o co najmniej kilka lat tancerką i aktorką. Z drugiego związku miał narodzić się w 1944 r. syn o nieznanym imieniu 5 . Świadectwa na ten temat są bardzo skąpe i niejednoznaczne.

\section{Pokonanie niepełnosprawności}

Niezwykle istotną rolę dla wychowania Ireneusza odegrała korespondencja matki z Untanem, czeskim akrobatą bez rąk, sławnym u schyłku XIX w. Matka poznała go w latach swojej młodości podczas występów w Rydze. On to w listach - korespondencję nawiązała matka Ireneusza krótko po narodzinach bezrękiego syna - doradził jej,

${ }^{4}$ Dopiero w 1928 r. na podstawie tajnego porozumienia między rządami Polski i Łotwy wywłaszczeni ziemianie otrzymali rekompensaty za utracone majątki w łącznej wysokości 5 milionów łatów w złocie. Wypłaty zakończono w grudniu 1937 r. Można domniemywać, że Platerowie, którzy byli najbogatszą polską rodziną na Łotwie, otrzymali najwyższe odszkodowanie (Jekabson, 1993, s. 38).

${ }^{5}$ Konarski podaje nazwisko Janina Radke (Konarski, 1967, s. 93; Plater Zyberk, 1931, ss. 209-211; „Rozmowa z Ireneuszem Plater Zyberkiem”, 1930, s. 10). 
aby nie krępowała nóg dziecka i umożliwiła mu rozwinięcie się naturalnych zdolności nóg. Tak się też stało, dziecko opanowało umiejętność ubierania się, jedzenia i załatwiania potrzeb fizjologicznych przy pomocy dolnych kończyn (Plater Zyberk, 1931, ss. 39-42, 51-52, 111).

Plater-Zyberk posiadł również umiejętność swobodnego pisania przy pomocy stóp, co wykorzystano później jako chwyt reklamowy jego debiutanckiej powieści. Jako dwudziestolatek ukończył eksternistycznie gimnazjum ziemiańskie w Warszawie, przyjeżdżał raz w roku do Polski i zaliczał wymagane egzaminy (Plater Zyberk, 1931, ss. 129-130; „Ireneusz Plater”, ok. 1960, s. 1). Opanował biegle języki rosyjski, niemiecki i francuski, słabiej, zapewne na poziomie komunikowania się w sytuacjach codziennych, angielski i duński. W domu rodzinnym posługiwano się na co dzień językiem polskim, przede wszystkim za sprawą matki.

Autor Życia bez rąk poświęca cały rozdział spotkaniu z profesorem Franciszkiem Chłapowskim (Wrzosek, 1937, ss. 302-303), wybitnym lekarzem i profesorem, który przyjechał do Wabola, aby zbadać jego przypadek. Okazuje się - jak czytamy w autobiografii - profesor poznał i gruntownie przebadał 28 osób urodzonych bez rąk. Przeważnie były to osoby bezradne, całkowicie uzależnione od rodziny lub opiekunów, niektórzy zarabiali na swoje utrzymanie żebraniem lub publicznymi występami w cyrku. Jedynie cztery osoby, włączając naszego bohatera, przejawiały zainteresowania intelektualne, wyrażane przez edukację szkolną, twórczość artystyczną lub badania naukowe (Plater Zyberk, 1931, ss. 103-117).

$\mathrm{Z}$ autobiografii często przebija motyw radzenia sobie w rozmaitych okolicznościach. Jest to właściwie jedno z głównych przesłań książki. Ireneusz Plater-Zyberk nie chce uchodzić za kogoś, kto jest skazany wyłącznie na litość i łaskawość innych. Wspomina zdarzenie, które miało miejsce w czasie prac polowych, zapewne w czasie I wojny światowej:

Praca wrzała. I tylko jakiś wyrostek, odbierający z pod młocarni worki i składający je na furę, ociągał się z robotą i ruchami swemi szedł z żółwiem w zawody. Leń był zresztą znany.

Zirytowany tą rozmyślną ślamazarnością, zakrzyknąłem ostro na niego. A działo się to w czasach, gdy pierwszy wiew rewolucji przemykał już nad krajem.

Skarcony chłopak uniósł hardo głowę i, patrząc mi prosto w oczy, wycedził dobitnie:

- A niech by tak pan sam spróbował, jakie to lekkie.

Nastąpiła chwila ciszy. Ten i ów osłupiał, zadziwiony bezczelnością chłopca. Niejeden w duszy zatarł dłonie, $w$ przeczuciu mej spodziewanej kompromitacji.

Lecz byłem wówczas młody i mocny. A że los nie poskąpił mi siły zębów i karku, więc uchwyciłem zębami cetnarowy wór zboża i jednym rzutem wwaliłem go w furę.

Nie pamiętam, by kiedykolwiek młocka szła tak raźno, jak dnia owego, aż do późnego wieczora (Plater Zyberk, 1931, ss. 231-232).

W pamięci krewnych Ireneusz Plater zapisał się jako osoba niezwykle sprawna, radząca sobie $\mathrm{w}$ rozmaitych sytuacjach. W okresie międzywojennym cieszył się 
znaczną popularnością nie tylko z powodu niepełnosprawności, lecz jeszcze bardziej ze względu na umiejętności. Róża Thun pisze, że umiał grać nogami na fortepianie, świetnie tańczył, jadł sztućcami, potrafił wycierać pot z twarzy chusteczką do nosa trzymaną palcami stopy (Thun, 2014, s. 29). Ireneusz Plater-Zyberk nie wstydził się swojej ułomności, w jakiejś mierze uczynił z niej swój znak i wizytówkę. Na ilustracji w tygodniku „Światowid” (1927, s. 15) widzimy go, jak pisze stopą, podobnie w wywiadzie opublikowanym na łamach tygodnika „Kino” zamieszczone są próbki tekstu pisanego stopą i przy pomocy ust („Rozmowa z Ireneuszem Plater Zyberkiem”, 1930, s. 10). Z kart autobiografii przebija myśl, że niepełnosprawność przyjmuje autor jako zrządzenie losu, że brak rąk mu doskwiera, ale nie czyni życia mniej pięknym. Warto przy tym zwrócić uwagę na pewien rys jego skromności i dobrego wychowania, które wyniósł z domu rodzinnego. Zdarzenie z lat młodzieńczych stanowi wymowny przykład postawy wyrażającej szacunek dla innych:

Aż któregoś dnia nagła myśl zbawcza, co miała ulżyć mej rzekomej niedoli, olśniła Matkę moją:

- Wiesz, Irenku, kupię ci szeroką luźną pelerynę. Będzie ci fałdzisto z ramion opadać i nada twej postaci taką naturalność, że nie będziesz prawie uwagi zwracać na siebie. Dobrze?

Potrząsnąłem przecząco głową i roześmiałem się.

- Nie, Mamusiu, niech już lepiej będzie zwykłe palto z pustymi rękawami. Bo niech mamusia sobie wyobrazi taką sytuację. Przedstawiam się komuś obcemu. Ten, nie podejrzewając, co ukrywa peleryna, wyciąga rękę na powitanie. Potrzyma ją chwilę przede mną, poczem nagle wyrżnie mnie w pysk, w mniemaniu, że mu odmawiam podania ręki! Miła perspektywa! (Plater Zyberk, 1931, s. 91).

Ireneusza Platera postrzegano przez pryzmat niepełnosprawności, na pewno budził ciekawość wśród osób postronnych. Nie można jednak mówić o powszechnym ostracyzmie wobec jego osoby, zwłaszcza w środowisku ziemiańskim, gdyż był powszechnie lubiany i uchodził za duszę towarzystwa. Miał przy tym opinię kobieciarza i lekkoducha, który bez skrupułów wydaje pieniądze własne i rodziny. Potrafił w nocy zjawić się w domu brata Ignacego wraz z kapelą cygańską, za której występy zresztą brat musiał zapłacić (Thun, 2014, s. 29).

\section{Literackie doświadczenia}

Początek aktywności artystycznej Plater-Zyberka przypada na drugą połowę lat 20. ubiegłego wieku. Wcześniej, jeśli wierzyć autobiografii, Ireneusz próbował szczęścia jako współwłaściciel domu handlowego, jako administrator cukrowni i pośrednik finansowy. Z różnym skutkiem, zwłaszcza że przez krewnych i znajomych postrzegany był rozmaicie. Jedynie część rodziny uważała go za „odszczepieńca”, który nie pasuje 
do arystokracji. U źródeł takiej postawy tkwiły bez wątpienia niepełnosprawność i popełniony mezalians, taki przynajmniej obraz tworzy autor na kartach $\dot{Z} y c i a ~ b e z ~ r a k^{6}$. Nie mamy żadnych przekazów, jak oceniano Irenusza Platera w latach 30. ubiegłego wieku, gdy stał się uznanym reżyserem i producentem filmów dokumentalnych. Na łamach ówczesnej prasy dość często wypowiadał się jako krytyk filmowy i przedstawiciel władz organizacji producentów filmów dokumentalnych.

$\mathrm{Z}$ przymrużeniem oka należy potraktować pierwsze próby literackie $\mathrm{w}$ dzieciństwie. Dziesięciostronicowa nowela - o której pisze w Życiu bez rąk - ukazywała perypetie ucznia szóstej klasy, któremu rodzice zabronili używać pomady do włosów. Opowiadanie nie spotkało się z uznaniem matki, która zresztą zabraniała używania kosmetyków (Plater Zyberk, 1931, ss. 123-125).

Zachowana spuścizna pisarska Plater-Zyberka to dwie powieści i autobiografia. Debiut książkowy Kobiety i żony czyli tajemniczy Andrzej ukazał się prawdopodobnie pod koniec 1926 r. Książka była polemiką z utworem Magdaleny Samozwaniec Mężowie i mężczyźni, w którym autorka upowszechniała hasła zbliżone do późniejszego feminizmu. Tom składał się z listów otwartych do pisarki i dziewięciu wymienionych z imienia kobiet. Kończy się wyimaginowaną rozmową z Magdaleną Samozwaniec na temat siły i słabości, niestałości i banalności kobiet. W usta pisarki - chociaż nie wymienionej z nazwiska - wkłada przewrotną polemikę, w gruncie rzeczy autokrytykę własnej książki:

Posądzasz mię o ślepy egoizm solidarności kobiecej. Nie biorę ci bynajmniej za złe, że wytykasz nasze wady. Przeciwnie. Obrzydliwą natomiast jest twoja stronniczość w traktowaniu tematu. Tytuł twej książki nie odpowiada jej intencjom. Winna się ona nazywać „Kobiety i zmysły”, albo „Historia dziewięciu ciał (Plater Zyberk, b.d., ss. 113-114).

Następną powieścią był dwutomowy kryminał polityczny i szpiegowski Tajemnica stanu (1927). Fabuła osnuta jest wokół głośnej zbrodni z 1913 r., kiedy to barona Jana Bispinga oskarżono o zamordowanie księcia Władysława Druckiego-Lubeckiego. Barona uznano winnym i skazano na więzienie, które jednak zamieniono na areszt domowy. W 1923 r. przeprowadzono rewizję procesu i Bispinga uniewinniono (Szenic, 1975, ss. 404-471). Nazwiska pierwowzorów bohaterów i nazwy miejscowości zostały wprawdzie zmienione, jednak okoliczności mordu i sposób prowadzenia opisu nie pozostawiają wątpliwości co do źródła inspiracji. Plater-Zyberk odwołuje się w powieści do aktualnych wydarzeń, z których tworzy rozbudowane wątki, jak na przykład

${ }^{6}$ Na podstawie ostatnich ustaleń należy złagodzić tezę o krytycznym stanowisku arystokracji wobec Ireneusza Plater-Zyberka, którą przedstawiłem w artykule z 2013 roku. Surowość w ocenie relacji między nim a częścią środowiska ziemiańskiego wynikła być może z nazbyt jednostronnej oceny przekazów zamieszczonych na kartach Życia bez rąk, a przede wszystkim niedostępności w owym czasie innych źródeł (Zawisza, 2013, s. 134; por. Plater Zyberk, 1931, ss. 224-225, 272-274, 276-278 i in.). 
wybuch prochu w cytadeli warszawskiej 13 października 1923 r. czy walki z bandami sowieckimi na wschodzie Polski.

Sama autobiografia Życie bez rąk nawiązuje do gawędy szlacheckiej mimo krytycznego i pełnego ironii stosunku autora do ówczesnego ziemiaństwa. Opowieść ma strukturę retrospektywną, autor omawiając bieżące wydarzenia często odwołuje się do epizodów z przeszłości. Plater zwraca uwagę na problemy, a nie na ścisłą chronologię. Struktura wspomnień wydaje się być nieco chaotyczna mimo prób jej uporządkowania i zamknięcia w tematyczne rozdziały: „Urodziłem się”, „Moja Matka”, „Czy owoc zakazany jest zawsze najsłodszy”, „Jeden z 28”, „Świat zewnętrzny w pryzmacie ułomności”, „Małżeństwo”, „Wszystkim na złość”, „Kobieta i ja”. Znakomite opisy przyrody i wciągające, niekiedy porywające sceny kontrastują z nudnymi rozważaniami o życiu; często są to refleksje znanych myślicieli, których Plater przywołuje jako autorytety dla podparcia własnych hipotez.

\section{Fascynacje filmowe}

W dorobku Ireneusza Plater-Zyberka mamy cztery filmy fabularne i nieznaną bliżej liczbę filmów dokumentalnych. Dziesiątą muzą zainteresował się on prawdopodobnie pod wpływem brata stryjecznego Stefana Plater-Zyberka (1891-1943), znanego fotografa i właściciela agencji fotograficznej Photo-Plat („Ireneusz Plater”, ok. 1960, s. 2; Konarski, 1967, s. 91) i Kazimierza Czyńskiego (1891-1956)7. Ostatni z wymienionych wyreżyserował film sensacyjny „Martwy węzeł” (1927) według scenariusza naszego bohatera (Jewsiewicki, 1966, s. 165; Banaszkiewicz \& Witczak, 1989, ss. 232, 288). Akcja filmu zaczyna się w Nowym Jorku, gdzie dwie kobiety - matka i córka są szantażowane przez tajemniczego Chińczyka i w efekcie uciekają przed nim do Europy. Dalej akcja rozgrywa się wyłącznie na wschodzie Polski. Krytycy zarzucali filmowi, że jest składanką nieco przypadkowych scen, przez co fabuła stała się mało czytelna. Najważniejsze walory filmu to pokazy strzelaniny i brawurowy pościg na motocyklach. Był to pierwszy w polskim kinie film kaskaderski, a w rolę sekretarza i obrońcy uciekających kobiet wcielił się Plater. Wystąpił w filmie jako Neri Prattl stylizowany anagram imienia i nazwiska - i był to jego debiut jako współproducenta, scenarzysty i aktora:

Szczytem wyczynów bezrękiego aktora była jego ucieczka na koniu. Koń galopował po poboczu drogi tak szybko, że moja żona wioząca operatora [kamery - przyp. R.Z.] ledwo

7 Witold Rychter w swoich wspomnieniach pisze, że to Ireneusz Plater-Zyberk występował pod pseudonimem Kazimierz Czyński. Jednak dotychczasowe ustalenia przeczą takiej opinii (Rychter, 1985, s. 162; Kalendarz Wiadomości Filmowych, 1929, ss. 152, 486; Kalendarz Wiadomości Filmowych, 1931, s. 336; Filmpolski.pl. Internetowa baza filmu polskiego, b.d.). 
mogła nadążyć za jeźdźcem. Ścigający go na samochodzie Ford T strzelali doń bez opamiętania i w końcu rzekomo trafili. Bezręki jeździec spadł w galopie z siodła na twarde pobocze drogi, koziołkując poprzez płytki rów na łąkę. Wyglądał potem, jakby mu się nic nie stało, ale musiał jednak kilka dni w łóżku leczyć silne potłuczenia (Rychter, 1985, s. 166).

Rok później Ireneusz Plater wyreżyserował według własnego scenariusza prostą komedię sensacyjną pod tytułem „Milionowy spadkobierca” (1928), a trzy lata później jej rozszerzoną wersję „Igraszki pieniądza” (1930). Na udźwiękowienie filmu nie udało się zdobyć środków. Oba filmy zrobiły klapę i nie zyskały uznania publiczności.

Jerzy Toeplitz, czołowy ówczesny krytyk filmowy, ocenił „Igraszki pieniądza” bardzo surowo, wytykając elementarne błędy warsztatu. Sugerował reżyserowi, aby w przyszłości zrezygnował z fabuły i poprzestał na montażu ciekawych, eksperymentalnych zdjęć, których w filmie nie brakowało (JBT, 1930, s. 9; Armatys \& Armatys, 1988, s. 210). Tak się też w niedalekiej przyszłości stało, Ireneusz Plater-Zyberk został jednym z bardziej uznanych reżyserów i producentów filmów dokumentalnych. Liczba zrealizowanych przez niego filmów krótko- i średniometrażowych nie jest znana, gdyż oprócz kilkudziesięciominutowych reportaży, tworzył kilkuminutowe relacje i dokumenty kronikarskie, będące rejestracją konkretnego wydarzenia lub prezentacją miejsca.

Do naszych czasów zachował się jedynie film „Salve Regina” (1935), reportaż z wielkiej jubileuszowej pielgrzymki do sanktuarium Matki Boskiej w Piekarach na Górnym Śląsku (Wyżyński, 2007, s. 478; Kuźnik, 2012). W filmie tym reżyser wykorzystał kamery z kilku planów, dzięki czemu powstał obraz dynamiczny, pełen ruchu i niespodziewanych zmian. Na korzyść filmu przemawiają: doskonałe zdjęcia i dobra ścieżka dźwiękowa, łącząca przekaz z uroczystości i podkład studyjny. Dziś jest to oczywiste, ale wtedy dominował w produkcji dokumentalnej przekaz linearny, diachroniczny.

Wyjątkowe miejsce w twórczości Ireneusza Plater-Zyberka zajmuje „Zew trombity” (1934), film pokazujący życie górali huculskich we Wschodnich Karpatach. Dokument był oceniany bardzo wysoko, reprezentował polskie kino na pokazach za granicą. Prawdopodobnie nie zachowała się żadna kopia i film znamy tylko z entuzjastycznych recenzji i nielicznych zdjęć reklamowych. Osnową reportażu - jak pisał Karol Ford - jest stary hucuł, który opowiada grupie harcerzy o swojej krainie, o życiu mieszkańców, szczególnie zwracając uwagę na obrzędy doroczne i rodzinne:

$\mathrm{Na}$ „Zew trombity” składają się przepiękne zdjęcia kilku najlepszych operatorów polskich (Vlassak, Steinwurzel, Kryński i inni), zespolone w doskonałą całość w reżyserji Ireneusza Plater-Zyberka. Dzięki zręcznemu pomysłowi (opowiadanie starego Hucuła) oglądać możemy luźne napozór ze sobą związane fragmenty w pewnej jednak kolejności logicznej. Na specjalne wyróżnienie zasługują piękne sceny górskie, modlitwa starego Hucuła, wesele, procesja i szereg widoków skał, gór i potoków (K.F., 1934, s. 3).

Równie entuzjastycznie pisała Wanda Kalinowska na łamach tygodnika „Kino”. W jej relacji należy zwrócić uwagę na liczbę mnogą w nazwisku twórców filmu. Być 
może miała na myśli wspomnianego wyżej Stefana Plater-Zyberka, który wspierał Ireneusza w rozwijaniu pasji filmowej i mógł mieć udział w powstaniu filmu:

Piękna, artystyczna forma, dobre wykonanie, krótkie zwięzłe objaśnienia, zręcznie powiązane etapy życiowe, trzymają widza w napięciu. A przecież to tysiąc metrów taśmy! [...]. Film, wyświetlany w dodatku do „Wesołej Wdówki”, przyjęto entuzjastycznie i nie szczędzono mu gromkich oklasków, co jest rzadkością u nas.

Powinno to zachęcić p.p. Plater-Zyberków do dalszej produkcji w tym rodzaju. Montaż bez zarzutu. Wspaniałe plenery. Dobry dźwięk. Odpowiednia, bardzo ładna ilustracja muzyczna (Wan. Kal., 1935, s. 14).

Należy pamiętać, że reportaż o Huculszczyźnie, wyświetlany przed głównym obrazem fabularnym, wzbudzał niejednokrotnie większe zainteresowanie widzów niż właściwy film. Nowak-Zaorska przytacza obszerny fragment recenzji w „Wieczorze Warszawskim” (nr 69 z 1935 r.), gdzie „Zew trombity” wyraźnie nazwano filmem etnograficznym (Nowak-Zaorska, 1969, s. 152). O innym dokumencie Plater-Zyberka „Rzeczy ciekawe" nie mamy dotychczas żadnych szczegółów, poza wzmianką, że był wyświetlony na pokazie w Paryżu w grudniu 1935 r. (Nowak-Zaorska, 1969, s. 166).

Dzięki filmowi „Martwy węzeł” i okazjonalnie zamieszczanym na łamach prasy zdjęciom Ireneusz Plater-Zyberk zyskał dużą popularność. Jego aktywność zawodowa nie wpłynęła w żaden sposób na zmianę postrzegania roli niepełnosprawnych w społeczeństwie. Pierwszym odruchem przygodnych obserwatorów, co opisuje w różnych sytuacjach na kartach autobiografii, była ciekawość i częste pytania, czy brak rąk to następstwo udziału w wojnie światowej. Chłopcy, gazeciarze sprzedający stołeczną prasę, dziwili się, jak sobie radzi w życiu codziennym:

- Patrzcie no! Bez rąk! To ci dopiero! A jak on je! Co on robi” - słyszę wokół przytłumione pytania.

Kolporterskiej gromady dopada starszy kolega.

- Jakto, co robi, - oburza się tak głośno, bym go mógł usłyszeć, - on to wszystko robi. Cóż to, nie widzieliście go w filmie? Golił się sam i strzelał z rewolweru do Junoszy Stępowskiego. Prawda, panie hrabio, że to wszystko tak jest, jak mówię.

Podbiega do mnie. Ale kiedyż to ja hrabiego ostatnio widziałem? Chyba ze dwa lata? (przedwczoraj mi dziennik sprzedał).

- A drobne, w prawej kieszonce? Jak zwykle? To już wiem, co dać: „Czerwoniak”, „Dobry Wieczór” i dzisiejsze „Kino”, prawda? dać? (Plater Zyberk, 1931, ss. 72-73)

Dorobek Ireneusza Plater-Zyberka nie jest szczególnie bogaty, również jego ocena nie wypada jednoznacznie. Dwie wydane powieści nie wytrzymały próby czasu, reprezentują przeciętny poziom artystyczny i literacki. Należy ubolewać, że z licznych 
zrealizowanych filmów zachował się tylko jeden film dokumentalny, bardzo dobry warsztatowo i kompozycyjnie reportaż „Salve Regina”. Według pomysłu Ireneusza Plater-Zyberka powstała w 1935 r. jedna z najciekawszych polskich komedii dwudziestolecia międzywojennego „ABC miłości” (Armatys \& Armatys, 1988, ss. 303, 332). Plater stanowi rzadki w tym czasie przykład niepełnosprawnego, któremu udało się osiągnąć znaczącą, na własną miarę, karierę artystyczną. Można go przy tym uznać za jednego z prekursorów polskich filmów etnograficznych.

Osnute tajemnicą są ostatnie lata jego życia. Wojnę spędził prawdopodobnie u krewnych lub przyjaciół w Austrii i zmarł w Feldkirch w 1946 r. (Konarski, 1967, s. 92). Róża Thun pisze, że wuja Irenka nigdy nie poznała, bo wyjechał do Szwajcarii i kontakt się urwał (Thun, 2014, s. 29). Nieznane pozostają losy domniemanego syna ze związku z Ireną Radko, nie wiemy również, czy po rozstaniu z Kozieradzką zawarł powtórnie związek małżeński.

Wydaje się niezrozumiałe, dlaczego tak ciekawa postać nie znalazła dotąd swojego miejsca w literaturze fachowej, ani tym bardziej w literaturze popularnej i w mediach. Wszyscy, którzy omawiali twórczość filmową Plater-Zyberka, pomijali zupełnie wątek niepełnosprawności. Na pewno nie może on być podstawą do wartościowania i oceniania filmów, ale powinien zwrócić uwagę na osobę twórcy. Właśnie Ireneusz Plater-Zyberk powinien stać się przykładem kariery i swoistego awansu kulturowego - gdyż miejsce $\mathrm{w}$ hierarchii społecznej $\mathrm{z}$ racji urodzenia mimo wszystko posiadł - $\mathrm{w}$ dwudziestoleciu międzywojennym. Nie mniej istotne znaczenie ma kresowe pochodzenie naszego bohatera, co stanowi dodatkowy bodziec do podjęcia dalszych poszukiwań. Niedostępność lub brak źródeł do biografii sprawiają, że całe mnóstwo niezwykłych osób odchodzi w zapomnienie. Tymczasem każdy życiorys i każda biografia - jak pisała Małgorzata Ostrówka - umożliwiają nowe, inne spojrzenie na losy społeczności polskiej na Kresach północno-wschodnich (Ostrówka, 2004, ss. 311-323). Gdy wiele lat temu Marek Plater-Zyberk namawiał mnie do zainteresowania się życiem i twórczością jego przodka stwierdził, że to nie tylko dobry przykład dydaktyczny dla młodzieży, dla dziennikarzy i polityków, lecz przede wszystkim świetny materiał na hollywoodzki film.

\section{Bibliografia}

Armatys, B., \& Armatys, L. (1988). Historia filmu polskiego (T. 2: 1930-1939). Warszawa: Wydawnictwa Artystyczne i Filmowe.

Banaszkiewicz, W., \& Witczak, W. (1989). Historia filmu polskiego (T. 1: 1895-1929). Warszawa: Wydawnictwa Artystyczne i Filmowe.

Filmpolski.pl. Internetowa baza filmu polskiego. (b.d.). Pobrano 20 lipca 2014, z http://filmpolski.pl/fp/index.php?osoba=1184229 
Ireneusz Plater [biografia]. (ok. 1960). Maszynopis udostępniony przez Marka Plater-Zyberka. JBT [Jerzy B. Toeplitz]. (1930, wrzesień 12). „Igraszki pieniądza“ [recenzja]. Kurier Polski, s. 9. Jekabson, E. (1993). Stosunki polsko-łotewskie na przestrzeni dziejów. W E. Walewander (Red.), Polacy na Łotwie (ss. 23-44). Lublin: Redakcja Wydawnictw KUL.

Jewsiewicki, W. (1966). Polska kinematografia w okresie filmu niemego (1895-1929/1930). Łódź: Łódzkie Towarzystwo Naukowe.

K.F. [Karol Ford]. (1934, grudzień 30). Zew Trembity. Film o Huculszczyźnie. Kino, 5(52), s. 3. Kalendarz Wiadomości Filmowych. (1929). Warszawa: Wydawnictwo Ignacy Rotsztat-Miastecki. Kalendarz Wiadomości Filmowych. (1931). Warszawa: Wydawnictwo Ignacy Rotsztat-Miastecki. Konarski, S. (1967). Materiały do biografii, genealogii i heraldyki polskiej: źródła i opracowania (T. 4: Platerowie). Buenos Aires; Paris.

Kuźnik, G. (2012, grudzień 16). Salve Regina. Film o Piekarach Śląskich. Pobrano 20 lipca 2014, z http://piekaryslaskie.naszemiasto.pl/artykul/galeria/1656045,salve-regina-filmo-piekarach-slaskich,id,t.html

Latvijas Valsts vēstures arhīvs. (ok. 1897). F. 2706, apr. 1, lieta 117, ss. 179-180 (Krievijas 1895. gada tautas skaitǐšanas kurzemes, vitebskas un vidzemes guberņā materiali 1897 g.).

Łossowski, P. (1990). Łotwa nasz sąsiad: stosunki polsko-łotewskie w latach 1918-1939. Warszawa: Wydawnictwo Mozaika

Malahovskis, V. (2012). Plāteri (Broel- Plāteri). W I. Šuplinska i in. (Red.). Latgales lingvoteritoriālā vārdnīca. 2 sējumos [Lingvoterritorial'ny̌̆ slovar' Latgalii v 2 tomakh] (T. 1, ss. 563-567). Rēzekne: Rēzeknes Augstsskola.

Nowak-Zaorska, I. (1969). Polski film oświatowy w okresie międzywojennym. Wrocław; Warszawa; Kraków: Ossolineum.

Ostrówka, M. (2004). Dzieje rodziny wpisane w historię miasta (na przykładzie rodziny Grzybowskich z Krasławia na Łotwie). W A. Kuczyński \& M. Michalska (Red.), Kultura iświadomość etniczna Polaków na Łotwie. Tradycja i współczesność (ss. 311-323). Wrocław: Uniwersytet Wrocławski.

Plater Zyberk, I. (1931). Życie bez rąk. Warszawa.

Plater Zyberk, I. (b.d.). Kobiety i żony czyli tajemniczy Andrzej. Warszawa: Ludwik Fiszer.

Plater-Zyberk, I. (1927). Tajemnica stanu: powieść (T. 1-2). Warszawa: Ludwik Fiszer.

Rozmowa z Ireneuszem Plater Zyberkiem. (1930, sierpień 24). Kino, 1(25), s. 10.

Rubene, D. (2008). Przedstawiciele rodu Zyberków i Platerów-Zyberków w Inflantach i w Kurlandii oraz ich wkład w rozwój kulturalny regionu. W K. Barkovska \& A. Kazjukevičs (Red.), Polija un Baltija kultūras dialogā [Polska i kraje bałtyckie w dialogu kultur] (ss. 82-91). Daugavpils (Daugavpils Universitāte, Komparatīvistikas institūta almanahs, 12. Sējums, Polijas un Baltijas kultūras sakari, 2. Izdevums): Saule.

Rychter, W. (1985). Moje dwa i cztery kótka. Warszawa: Wydawnictwa Komunikacji i Łączności. Sardyko, F. (b.d.) [Wypisy z książek i relacje świadków na temat miejscowości Lìksna i Vabole, pisane w latach 90. XX w., każdy wpis odrębnie datowany]. Rękopis ze zbioru Muzeum Braci Skrindów, Wabol [Skrinda Dzimtas Muzejs, Vabole]. 
Sawicz, C. (2006). Wileńszczyzna. Kresy Rzeczypospolitej. Halinów: QLCO.

Szenic, S. (1975). Pitaval warszawski (3. wyd. poszerzone). Warszawa: Krajowy Instytut Wydawniczy.

Światowid. (1927, czerwiec 4). 4(23), s. 15.

Thun, R. (2014). Róża. Kraków: Znak.

Wan. Kal. [Wanda Kalinowska]. (1935, marzec 31). „Zew Trombity“. Kino, 6(13), s. 14.

Wrzosek, A. (1937). Chłapowski Franciszek (1845-1923). W Polski Słownik Biograficzny (T. 3: Brożek Jan - Chwalczewski Franciszek, ss. 302-303). Kraków: Polska Akademia Umiejętności.

Wyżyński, A. (2007). Salve Regina. W A. Garbicz \& M. Lis (Red.), Światowa encyklopedia filmu religijnego (s. 478). Kraków: Biały Kruk.

Zawisza, R. (2013). Das Leben ohne Arme. Irenäus Plater-Zyberk als Schriftsteller und Filmemacher (1896-1946). W D. Baldes \& I. Vingre (Red.), Deutsch-baltischer Kulturtransfer. Beiträge einer Tagung zur Aufarbeitung der nordosteuropäischen Literatur- und Kulturbeziehungen vom 3.-4. September 2012 in Daugavpils (ss. 129-143). Daugavpils: Academic Press "Saule".

Zawisza, R. (2014). Biografia nieobecna: wokół życia i twórczości Ireneusza Platera-Zyberka. W R. Skrzyniarz, E. Krzewska, \& E. Kuryluk (Red.) Biografia $w$ literaturze i sztuce (ss. 193-206). Lublin: Episteme. (Seria: Biblioteka Katedry Biografistyki Pedagogicznej, Nr 4).

\section{Streszczenie}

Ireneusz Plater-Zyberk (1896 lub 1897-1946) był literatem i twórcą filmowym, nieco awanturnikiem i bawidamkiem. Jego postać to niezwykły przykład niepełnosprawnego, który osiągnął w dwudziestoleciu międzywojennym znaczącą karierę. Ireneusz Plater-Zyberk pochodził z zamożnej rodziny ziemiańskiej, zamieszkałej w majątku Wabol na Łotwie. Urodził się bez rąk i w ówczesnej rzeczywistości miał pozostać na marginesie społeczeństwa. Dzięki wytrwałości matki udało mu się ukończyć jako ekstern gimnazjum w Warszawie. W swoim dorobku ma wspomnienia Życie bez rąk oraz dwie powieści. Ważną rolę odegrał Plater jako scenarzysta i reżyser, był m.in. współtwórcą pierwszego polskiego filmu z efektami kaskaderskimi „Martwy węzeł” (1927). Miał on również ogromne zasługi jako twórca filmów dokumentalnych i jednocześnie inspirator zmian w prawodawstwie dotyczącym produkcji filmowej. Tłem jego twórczości pisarskiej jest burzliwe i pełne przygód życie osobiste, romanse i popełniony mezalians, które z racji kalectwa były traktowane przez społeczność ziemiańską pobłażliwie i z dużą wyrozumiałością.

Słowa kluczowe: Plater-Zyberk; Łotwa; pisarz; film; reżyser; film dokumentalny; niepełnosprawny; bolszewicy; arystokracja 


\section{An Absent Biography. About the life and work of Ireneusz Plater-Zyberk}

\section{Summary}

Ireneusz Plater-Zyberk (1896-1946), was a writer and a film producer, adventurer and gallant. His life is an incredible story of the disabled individual who succeeded in an amazing career. Plater-Zyberk was born in a wealthy landowning family who lived at the estate of Vabole in Latvia. He was born without hands and at that time, due to his disability, was classified as "margins of society". Thanks to perseverance and commitment of his mother, he graduated as an extern student from high school in Warsaw, Poland. His career includes Life without Hands, memories, and two novels. He was a co-author of first movie in Poland with stunt effects Dead Node (1927), which unfortunately wasn't preserved. Also, he was recognized as a documentary creator as well as an initiator of film production regulations.

Keywords: Plater-Zyberk; Latvia; writer; film director; documentary film; disabled; the Bolsheviks; nobility 


\section{Ilustracje}

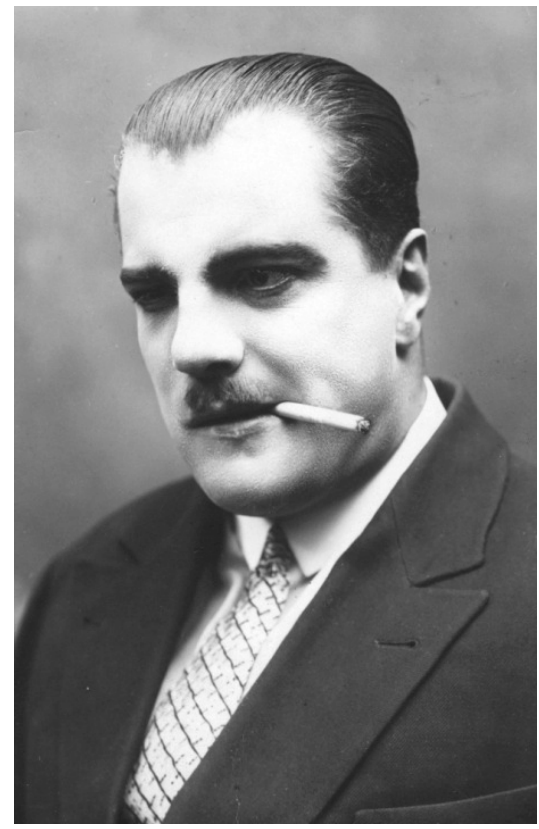

Fot. 1. Ireneusz Plater-Zyberk ok. 1927 r. (Narodowe Archiwum Cyfrowe, 1-P-2113)

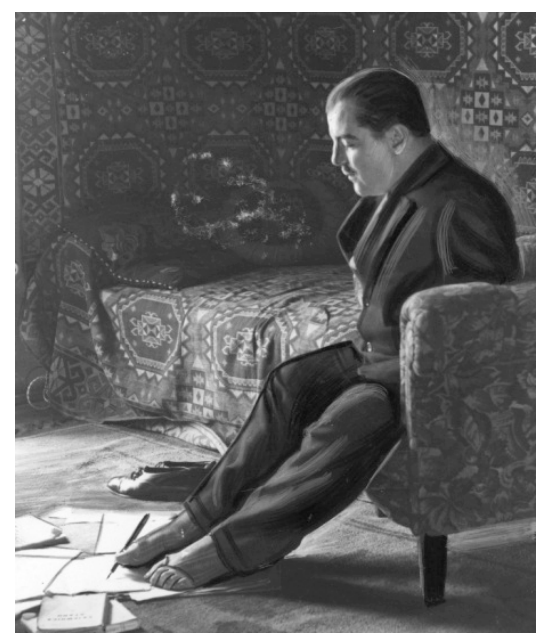

Fot. 2. Ireneusz Plater-Zyberk przy pracy pisarskiej, ok. 1927 r. (Narodowe Archiwum Cyfrowe, 1-P-2114) 


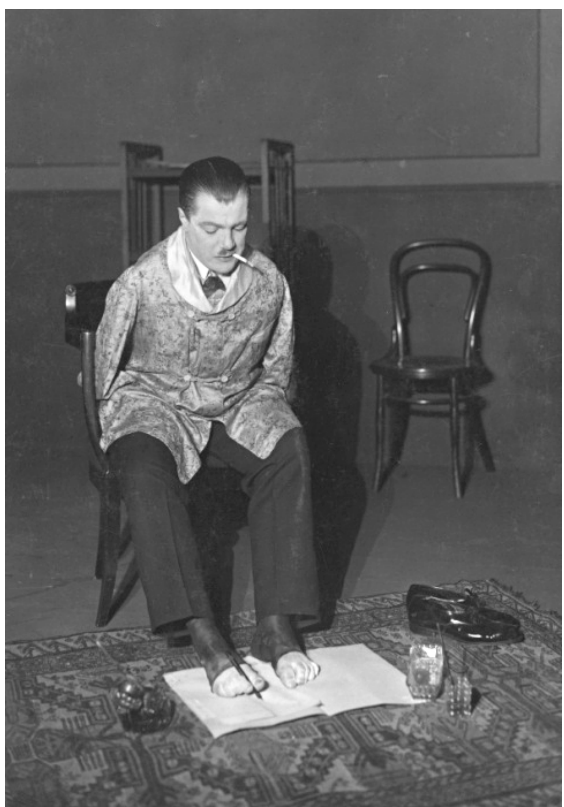

Fot. 3. Ireneusz Plater-Zyberk, ok. 1927 r. (Narodowe Archiwum Cyfrowe. 1-P-2115)

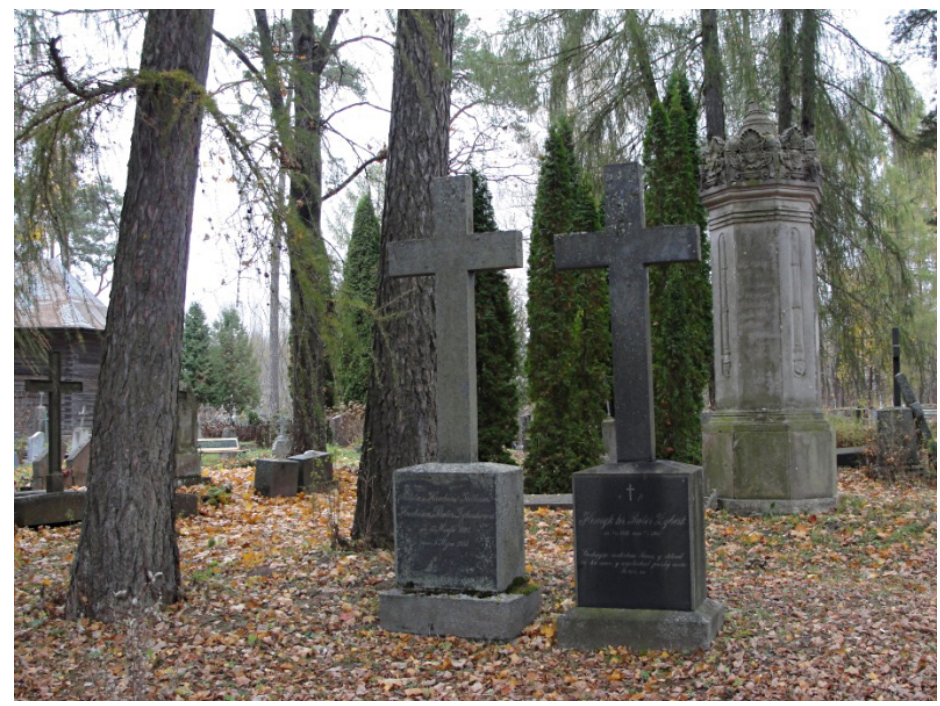

Fot. 4. Cmentarz w Patmale. Groby Adeli z hr. Keller i Henryka Plater-Zyberków, dziadków Ireneusza. Według tradycji ustnej obok nich pochowano w ziemnym grobie Teofila Plater-Zyberka, ojca autora Życia bez rąk. Fot. Robert Zawisza 


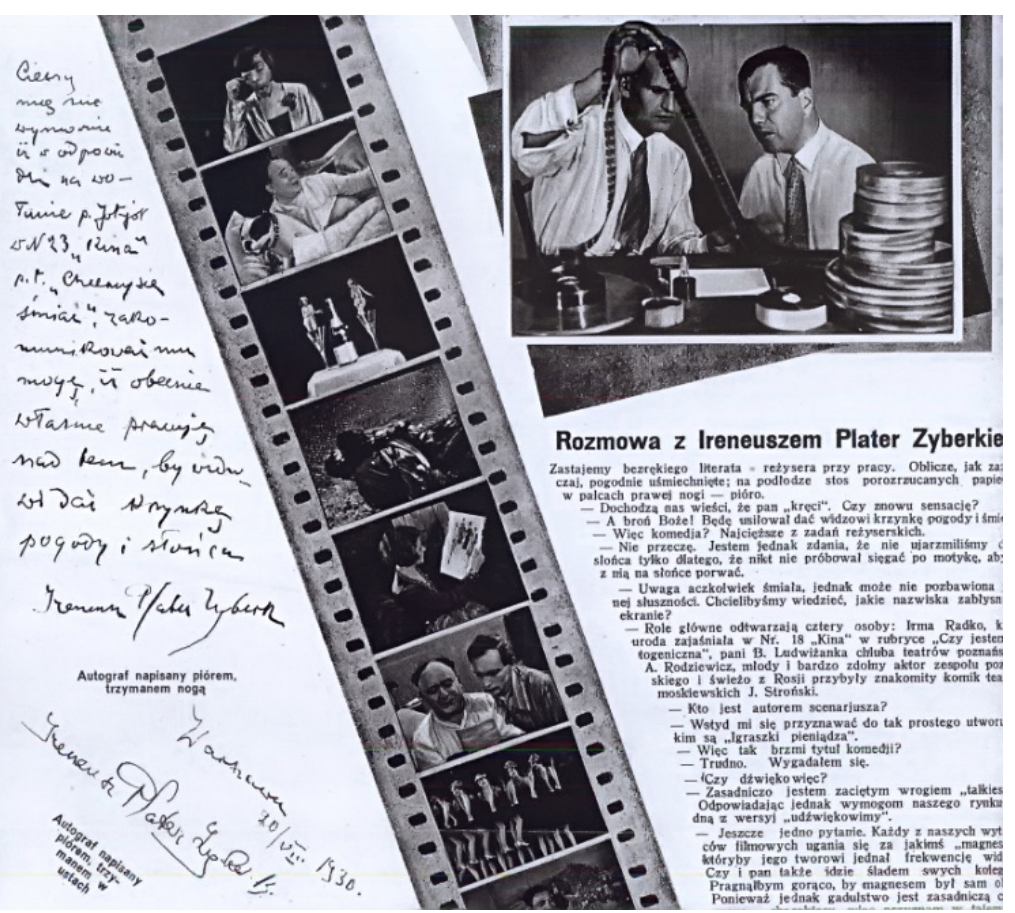

Fot. 5. Próbki pisma Ireneusza Plater-Zyberka, pisane stopą i ustami (tygodnik „Kino”, nr 25 z 1930 r.)

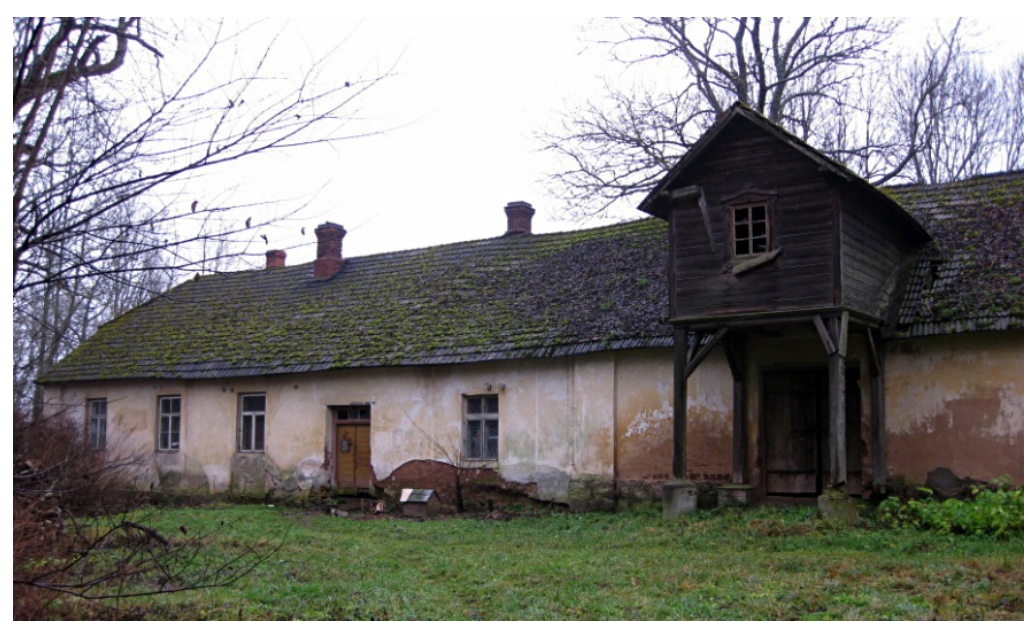

Fot. 6. Budynek gospodarczy z początku XIX w. w dawnym majątku Wabol. Fot. Robert Zawisza 


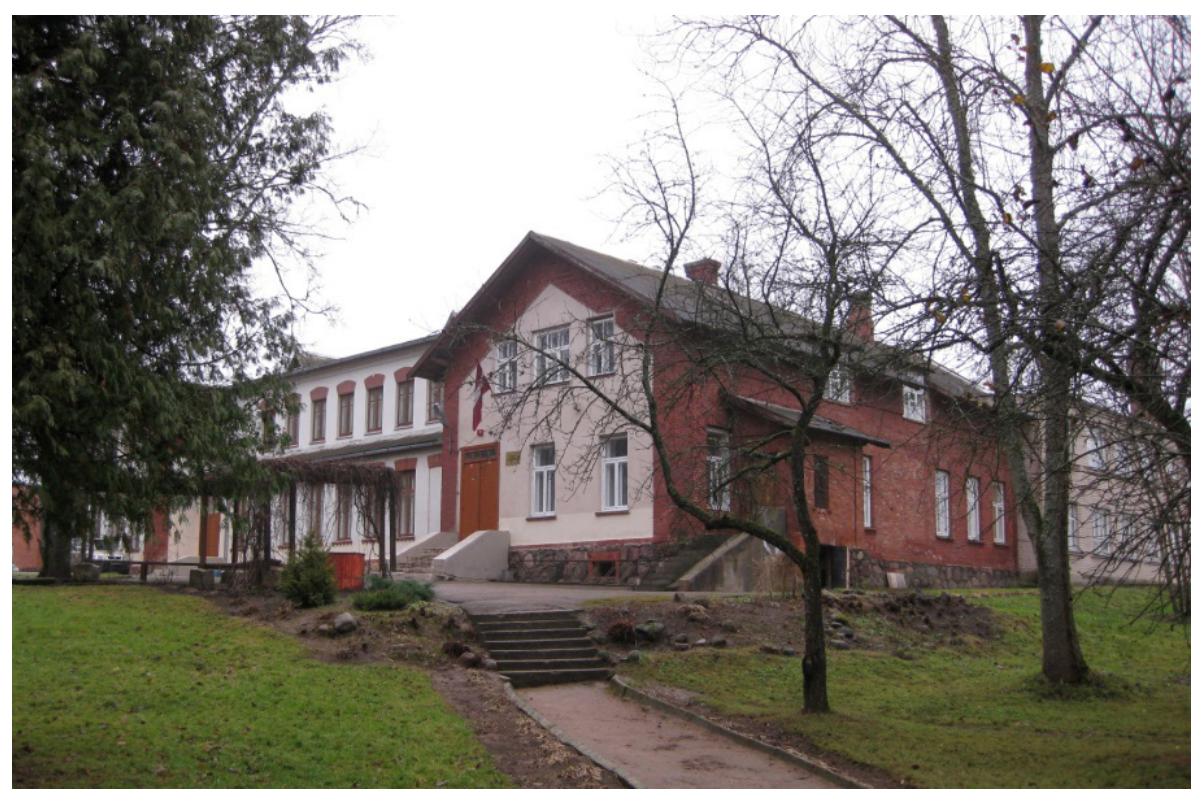

Fot. 7. Dawna wozownia i stajnia [?] w Wabolu, okres międzywojenny (Muzeum Braci Skrindów w Wabolu / Skrinda Dzimtas Muzejs, Vabole)

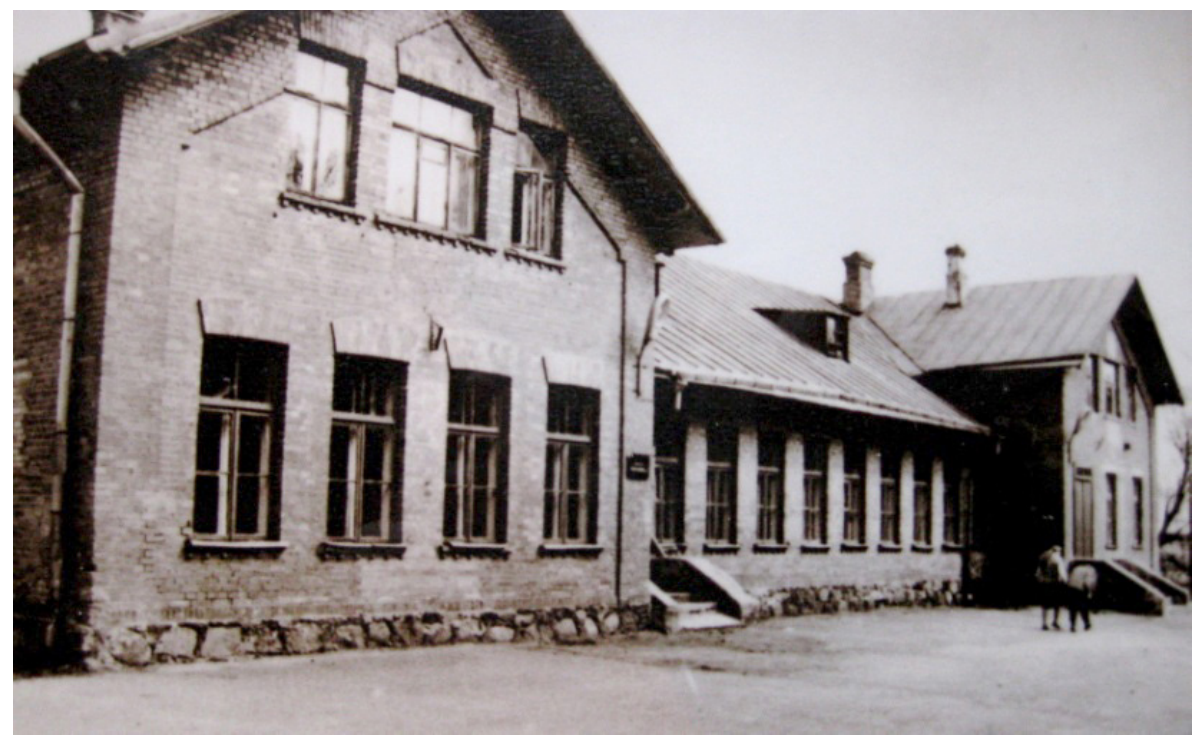

Fot. 8. Dawna wozownia i stajnia [?] w Wabolu, obecnie szkoła średnia. Fot. Robert Zawisza 